удк 616-092

DOI

\title{
ПРОЗАПАЛЬНИЙ ЦИТОКІН ЕНДОТЕЛІАЛЬНИЙ МОНОЦИТАКТИВУЮЧИЙ ПЕПТИД ІІ: ВМІСТ У СИРОВАТЦІ КРОВІ ПРИ ЦУКРОВОМУ ДІАБЕТІ
}

\author{
оЛ. А. Могильницька, О. В. Тузова \\ Хмельницька обласна лікарня \\ Миколаївський міжрегіональний інститут розвитку людини «Університет «Україна»
}

РЕЗЮМЕ. Досліджували вміст ендотеліального моноцитактивуючого пептиду II (ЕМАР-ІІ) у сироватці крові при цукровому діабеті 1-го та 2-го типів, встановлювали можливий зв'язок з показниками вуглеводного обміну. Виявлено підвищення вмісту ЕМАР-ІІ у сироватці крові при цукровому діабеті 1-го та 2-го типів. Рівень пептиду прямо корелював з вмістом глікозильованого гемоглобіну, глюкози крові. Підвищення вмісту ЕМАР-ІІ може бути одним з проявів ендотеліальної дисфункції при цукровому діабеті 1-го та 2-го типів, а порушення вуглеводного обміну може впливати на розвиток виявлених зрушень.

КЛЮчОВІ СЛОВА: ендотеліальний моноцитактивуючий пептид II, цукровий діабет, ендотеліальна дисфункція.

Вступ. Ендотеліальний моноцитактивуючий поліпептид-ІІ (ЕМАР-ІІ) - це мультифункціональний цитокін з прозапальною та антиангіогенезною активністю [5]. Він здатен впливати на прокоагулянтні функції ендотеліальних клітин, ймовірно, через вплив на тканинний фактор, а також хемотаксичний вплив на моноцити, гранулоцити [1]. У ендотеліальних клітинах ЕМАР-ІІ викликає експресію Е- та Р-селектину, виділення фактора Віллебранта та продукцію туморнекротичного фактора-альфа моноцитами [2].

EMAP-II бере участь у процесі реваскуляризації та відновлення тканини міокарда при інфаркті міокарда [3]. Блокада ЕМАР-ІІ моноклональними антитілами індукує ангіогенез та покращує відновлення серцевої функції після інфаркту міокарда через зменшення фіброзу серцевого м'яза та розмірів рубця, збільшує кількість капілярів та запобігає накопиченню моноцитів у вогнищі інфаркту [6].

Функціональний стан ендотелію характеризується, з одного боку, ендотелійзалежною ди- латацією, а з іншого - вмістом ендотеліальних вазоактивних факторів у сироватці крові. Ендотеліальна дисфункція - ранній та важливий крок у розвитку діабетичних ангіопатій [4].

Вплив EMAP-II на ендотеліальні клітини може бути одним із проявів розвитку ендотеліальної дисфункції. Проте в літературі відсутні дані про роль ЕМАР-ІІ при цукровому діабеті.

Метою нашого дослідження було вивчення вмісту ендотеліального моноцитактивуючого пептиду II в сироватці хворих на цукровий діабет 1-го та 2-го типів.

Матеріал і методи дослідження. Обстежено 166 осіб, з них 94 хворих на цукровий діабет 30 хворих на цукровий діабет 1-го типу, 64 хворих на цукровий діабет 2-го типу та 72 контрольні особи, які не страждають від цукрового діабету, серед них - 28 контрольних осіб молодого віку та 44 контрольні особи середнього віку.

Групи, в межах яких проводився аналіз, були відповідні за статтю та віком. Клініко-лабораторна характеристика представлена в таблиці 1.

Таблиця 1. Клініко-лабораторна характеристика обстежених осіб

\begin{tabular}{|l|c|c|c|c|}
\hline & $\begin{array}{c}\text { Цукровий діабет } \\
\text { 1-го типу }\end{array}$ & $\begin{array}{c}\text { Контроль } \\
\text { молодого віку }\end{array}$ & $\begin{array}{c}\text { Цукровий діабет } \\
\text { 2-го типу }\end{array}$ & $\begin{array}{c}\text { Контроль } \\
\text { середнього віку }\end{array}$ \\
\hline Кількість осіб & 30 & 28 & 64 & 44 \\
\hline Вік, років & $20,3 \pm 2,07$ & $19,96 \pm 2,06$ & $52,09 \pm 6,63$ & $51,06 \pm 6,08$ \\
\hline ІМТ, кг/м² & $20,37 \pm 2,19$ & $20,48 \pm 2,18$ & $29,81 \pm 7,44$ & $29,55 \pm 7,43$ \\
\hline Глікозильований гемоглобін, \% & $10,32 \pm 1,59 *$ & $5,33 \pm 0,45$ & $9,66 \pm 2,02^{* *}$ & $5,33 \pm 0,4$ \\
\hline Глюкоза крові натще, ммоль/л & $10,76 \pm 2,36^{*}$ & $4,6 \pm 0,57$ & $9,36 \pm 2,56^{* *}$ & $4,62 \pm 0,83$ \\
\hline Загальний холестерин, ммоль/л & $5,34 \pm 0,92^{*}$ & $4,14 \pm 0,51$ & $6,46 \pm 1,63$ & $4,98 \pm 1,72$ \\
\hline Тригліцериди, ммоль/л & $2,53 \pm 0,57^{*}$ & $1,46 \pm 0,29$ & $2,55 \pm 0,82$ & $2,15 \pm 0,81$ \\
\hline $\begin{array}{l}\text { Ліпопротеїди високої щільності, } \\
\text { ммоль/л }\end{array}$ & $1,03 \pm 0,2^{*}$ & $1,34 \pm 0,23$ & $1,03 \pm 0,18$ & $1,23 \pm 0,29$ \\
\hline $\begin{array}{l}\text { Ліпопротеїди низької щільності, } \\
\text { ммоль/л }\end{array}$ & $3,32 \pm 1,01^{*}$ & $2,63 \pm 0,4$ & $3,49 \pm 1,02$ & $2,97 \pm 0,87$ \\
\hline
\end{tabular}

Примітки: 1. *p<0,05 - статистично достовірна відмінність між групами 1 та 3;

2. ** $<<0,005$ - статистично достовірна відмінність між групами 2 та 4; 
Огляди літератури, оригінальні дослідження, погляд на проблему

Артеріальна гіпертензія спостерігалась у 23 (76,6\%) хворих, які страждають від цукрового діабету 1-го типу, у 41 (64 \%) хворого з цукровим діабетом 2-го типу та у 27 (61,3\%) осіб з контрольної групи середнього віку.

Визначення рівня ЕМАР-ІІ проводились імуноферментним методом із використанням сор6ційних колонок "Ampгег» (Amersham Lifesilence) та тест-систем "Amersham pharmacia biotech" (England). Дослідження проводили на плошковомy ELISA-аналізаторі «Stat Fax-303 Plus» (USA).

Результати представлені як середнє \pm стандартне відхилення. їх статистичну обробку прово- дили методами варіаційної та описової статистики за допомогою стандартного пакета статистичного розрахунку даних програми Microsoft Excel. Достовірність відмінностей середніх значень визначали за критерієм t-Стьюдента. Відмінність вважали достовірною при $p<0,05$. Кореляційний аналіз між рядами показників розраховували використовуючи коефіцієнт Пірсона.

Результати й обговорення. Нами виявлено, що вміст ЕМАР-ІІ в сироватці крові хворих на цукровий діабет 1-го типу складає $(4,62 \pm 1,91)$ нг/мл. У контрольній групі осіб молодого віку сироватковий рівень ЕМАР-ІІ склав $(1,25 \pm 0,76)$ нг/мл (рис. 1).

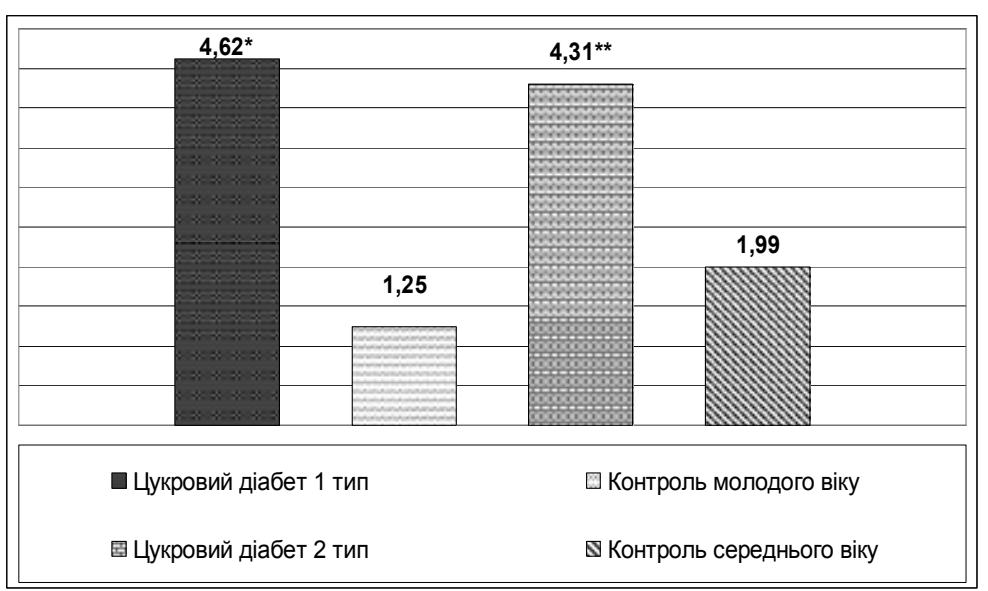

Рис. 1. Вміст ЕМАР-ІІ у сироватці крові хворих на цукровий діабет 1-го та 2-го типів.

* $p<0,0001$ - статистично достовірна відмінність між групою хворих на цукровий діабет 1-го типу та контрольною групою;

** $p<0,001$ - статистично достовірна відмінність між групою хворих на цукровий діабет 2-го типу та контрольною групою.

Рівень ЕМАР-ІІ у сироватці крові хворих на цукровий діабет 2-го типу склав $(4,31 \pm 2,17)$ нг/мл. У контрольній групі людей, котрі не хворіють на цукровий діабет, ЕМАР-ІІ у сироватці крові складає $(1,99 \pm 1,3)$ нг/мл.

При аналізі отриманих даних ми виявили статистично достовірне $(p=0,001)$ підвищення вмісту EMAP-II у сироватці крові хворих на цукровий діабет 1-го типу в 2,1 раза, порівняно з контрольною групою осіб з молодого віку.

Рівень ЕМАР-ІІ у сироватці крові хворих на цукровий діабет 2-го типу був статистично достовірно вищий в 3,6 раза, порівняно з контрольною групою осіб молодого віку ( $p=0,0001)$.

Підвищення рівня EMAP-II, яке було виявлено в результаті нашого дослідження у хворих на цукровий діабет 1-го та 2-го типів, може бути проявом ендотеліальної дисфункції та активації при вказаних патологічних станах.

Отже, вміст ЕМАР-ІІ був достовірно вищий у групах хворих на цукровий діабет як 1-го так і 2-го типів, порівняно з відповідними групами осіб без діабету. Це може вказувати на роль гіперглікемії у розвитку вказаних зрушень.
Роль гіперглікемії підтверджується даними кореляційного аналізу, в результаті якого виявлено прямий кореляційний зв'язок між глікозильованим гемоглобіном, глюкозою крові та рівнем EMAP-II у обстежених пацієнтів. При цьому коефіцієнт кореляції склав г=0,8 та 0,66 відповідно $(p<0,05)$ в групі хворих на цукровий діабет 1-го типу та $r=0,63$ та 0,6 відповідно $(p<0,05)$ в групі 3 цукровим діабетом 2-го типу.

Підвищення рівня EMAP-II, яке було виявлено в результаті нашого дослідження у хворих на цукровий діабет 1-го та 2-го типів, може бути проявом ендотеліальної дисфункції та активації при вказаних патологічних станах.

Висновки. Цукровий діабет 1-го та 2-го типів супроводжується підвищенням рівня EMAP-II у сироватці крові. Гіперглікемія пов'язана з підвищенням вмісту ЕMAР-ІІ у сироватці крові. Підвищення рівня EMAP-ІІ може бути одним з проявів розвитку ендотеліальної дисфункції при цукровому діабеті 1-го та 2-го типів.

Перспективи подальших досліджень. У перспективі доцільним $\epsilon$ вивчити вміст EMAP-II в сироватці крові хворих на цукровий діабет 1-го типу 
Огляди літератури, оригінальні дослідження, погляд на проблему

з мікроангіопатіями, у хворих на цукровий діабет 2-го типу з різною масою тіла, у осіб з ожирінням та синдромом полікістозних яєчників. Встановити зв'язки між даним фактором та іншими показниками ендотеліальної дисфункції.

\section{ЛІТЕРАТУРА}

1. Characterization of a novel tumor-derived cytokine. Endothelial monocyte activating polypeptide II / J. Kao, K. Houck, Y. Fan [et al.] // J. Biol. Chem. - 1994. - Vol. 269. P. 25106-25119.

2. Involvement of endothelial-monocyte activating polypeptide II in tumour necrosis factor-alpha-based anticancer therapy / T. E. Lans, R. van Horssen, A. M. Eggermont, T. L. ten Hagen // Anticancer. Res. - 2004. - Vol. 24. P. 2243-2248.

3. Potential role for antiangiogenic proteins in the myocardial infarction repair process / J. L. Thompson, J. A. Ryan, M. L. Barr [et al.] // J Surg. Res. - 2004. Vol. 116 (1). - P. 156-164.
4. Tooke J. E. Possible pathophysiological mechanisms for diabetic angiopathy in type 2 diabetes / J. E. Tooke // J. Diabetes Complications. - 2000. - Vol. 14. - P. 97-200.

5. Van Horssen R. Endothelial monocyte-activating polypeptide-II and its functions in (patho)physiological processes / R. van Horssen, A. M. Eggermont, T. L. ten Hagen // Cytokine Growth Factor Rev. - 2006. - Vol. 17 (5). P. 339-348.

6. Blockade of EMAP II protects cardiac function after chronic myocardial infarction by inducing angiogenesis / C. Yuan, L. Yan, P. Solanki [et al.] // J. Mol. Cell. Cardiol. 2015. - Vol. 79. - P. 224-231.

\title{
PROINFLAMMATORY CYTOKINE ENDOTHELIAL MONOCYTE ACTIVATING PEPTIDE II: SERUM LEVEL IN DIABETES
}

\section{@L. A. Mohylnytska, O. V. Tuzova}

\author{
Khmelnytskyi Regional Hospital \\ Mykolayiv International Institute of Development of a Man «University «Ukraine»
}

SUMMARY. There was investigated a serum level of endothelial monocyte activating peptide II in type 1 and 2 diabetes and possible relation with carbohydrate metabolism.

It was found an increased serum level of EMAP-II in type 1 and 2 diabetes. There was significant correlation between EMAP-II and HbAc1, blood glucose. The revealed change of EMAP-II serum level reflects an endothelial dysfunction in type 1 and 2 diabetes, alteration of carbohydrate metabolism could influence of this pathway.

KEY WORDS: endothelial monocyte activating peptide II, diabetes, endothelial dysfunction. 